\title{
MENINGKATKAN WAKTU AKTIF BELAJAR SISWA SEKOLAH DASAR MELALUI PEMANFAATAN MEDIA PEMBELAJARAN PENDIDIKAN JASMANI
}

\begin{tabular}{|c|c|}
\hline \multicolumn{2}{|c|}{$\begin{array}{c}\text { Ega Trisna Rahayu }{ }^{\mathbf{1}} \text {, Neneng Suningsih }{ }^{\mathbf{2}} \\
{ }^{1} \text { SDN Sarimulya 1, }{ }^{2} \text { Universitas Singaperbangsa Karawang } \\
\text { ega.trisna.rahayu@ @ staaff.unsika.ac.id } \\
\text { neneng@gmail.com }\end{array}$} \\
\hline Info Artikel & Abstrak \\
\hline $\begin{array}{l}\text { Sejarah Artikel: } \\
\text { Diterima Maret } 2020 \\
\text { Disetujui April } 2020 \\
\text { Dipublikasikan Juni } 2020\end{array}$ & $\begin{array}{l}\text { Tujuan penelitian ini adalah untuk memperoleh gambaran } \\
\text { mengenai "Pemanfaatan Media Pembelajaran Pendidikan } \\
\text { Jasmani Dalam Upaya Meningkatkan Waktu Aktif Belajar } \\
\text { Siswa". Metode yang digunakan dalam penelitian ini } \\
\text { adalah penelitian tindakan kelas (The Classroom Action } \\
\text { Research). Dalam desain yang di gunakan adalah model } \\
\text { siklus yang meliputi langkah-langkah perencanaan, } \\
\text { pelaksanaan, observasi, dan refleksi. Populasi yang di } \\
\text { gunakan dengan cara purposiv sampel, sebanyak } 32 \text { siswa } \\
\text { kelas III. Instrument yang digunakan adalah berupa catatan } \\
\text { lapangan (Duration Recoding) yaitu penggunaan waktu } \\
\text { aktif belajar pendidikan jasmani melalui observasi dengan } \\
\text { rerata 55\% sehingga di tentukan target capaian dengan } \\
\text { rerata } 80 \% \text {. Berdasarkan peneltian pada siklus I (Tindakan } \\
\text { I, II dan III) 80,43\%, dikarenakan sudah melampaui target } \\
\text { penelitian di cukupkan pada siklus II. Berdasarkan hasil } \\
\text { analisi data maka di peroleh kesimpulan pemanfaatan } \\
\text { media pembelajaran pendidikan jasmani cukup berarti } \\
\text { terhadap peningkatan waktu aktif belajar siswa SDN } \\
\text { Sarimulya } 1 \text { Kecamatan Kota Baru Kabupaten Karawang. }\end{array}$ \\
\hline & (2) \\
\hline
\end{tabular}

The purpose of this study was to obtain an overview of "Improvement of Physical Education Learning Media in an Effort to Increase Student Active Learning Time". The method used in this study is classroom action research (The Classroom Action Research). In the design used is a cycle model that includes the steps of planning, implementation, observation, and reflection. The population used by purposive sampling, as many as 32 students in class III. The instrument used was in the form of field notes (Duration Recoding), namely the use of active time learning physical education through observation with an average of 55\% so that the target set was achieved with an average of $80 \%$. Based on research in cycle I (Actions I, II and III) $80.43 \%$, Because it has exceeded the research target, it is sufficient in cycle II. Based on the results of data analysis, it was concluded that the use of physical education learning media was significant to increase active learning time for students of SDN Sarimulya 1, Kecamatan Kota Baru, Kabupaten Karawang. 


\begin{tabular}{ll}
\hline Alamat korespondensi: & e e-ISSN : 2721-7175 (online) \\
E-mail: Adirahadian@unsur.ac.id & p-ISSN : 2089-2341 (cetak)
\end{tabular}

\section{PENDAHULUAN}

Pendidikan jasmani merniliki peranan penting untuk membantu tercapainya tujuan pendidikan secara keseluruhan, sekaligus merespon tuntutan dunia pendidikan. sebab pendidikan jasmani bisa berfungsi sebagai wahana yang efektif dalam pembentukan akhlak siswa/ peserta didik ke arah yang lebih sempurna, seiring dengan pertumbuhan dan perkembangan menuju tercapainya manusia indonesia yang utuh, maju dan mandiri, Salah satu isi program pengajaran dari kurikulum Sekolah Dasar (SD) adalah mata pelajaran pendidikan jasmani yang berfungsi untuk membangun manusia seutuhnya. Secara spesifik adalah mengembangkan titik rnotorik melalui aktivitas jasmani dan olahraga. dan melatih kemampuan berupa disiplin. sportilitas, kejujuran, kerjasama, dan semangat yang tinggi.

Berdasarkan hasil pengarnatan yang dilakukan penulis terhadap siswa SDN Sarimulya 1 Desa Sarimulya Kecamatan Kota Baru Kabupaten Karawang, sebagian besar siswa SDN Sarimulya 1 antusias dan bersemangat dalam rnelaksanakan pembelajaran pendidikan jasmani, tetapi pada saat proses helajar berlangsung sebagian siswa sibuk dengan kegiatan masing-masing, mengobrol, bahkan hanya diam yang membuat waktu aktif belajar siswa menjadi tidak efektif. Salah satu materi pembelajaran dalam pembelajaran pendidikan jasmani adalah aktivitas altletik yang isinya lari, lompat. dan lempar. Dalarn pembelajaran atletik disekolah tersebut terlihat jumlah waktu aktif belajar sangat rendah. Hal ini terlihat dari banyaknya siswa yang diam karena harus rnenunggu giliran yang terlalu lama, hal ini terjadi karena terbatasnya sarana dan prasarana (media pembelajaran yang sangat terbatas).

Dari permasalahan diatas. penulis mencoba untuk mengatasi hal tersebut dengan memanfaatkan media pembelajaran pendidikan jasmnai. Pembelajaran pendidikan jasmani di SD sangat bermanfaat bagi perkembangan fisik dan motorik siswa, namun karena keadaan Iingkungan dan situasi sekolah yang kurang kondusif dalam hal ini keterhatasan fasilitas yang memadai membuat kegiatan pembelajaran pendidikan jasmani belum efektir dan basil belajarnya pun kurang memuaskan.

Minimnya fasilitas dan perlengkapan pendidikan jasmani yang dimiliki sekolah, menuntut guru Pendidikan jasmani untuk lebih kreatif dalam memberdayakan dan rnengoptimalkan penggunaan fasilitas dan perlengkapan yang ada. Kreativitas guru 
85 Neneng Suningsih ${ }^{1 *}$, Ega Trisna Rahayu ${ }^{2}$

Meningkatkan Waktu Aktif Belajar Siswa Sekolah Dasar

Melalui Pemanfaatan Media Pembelajaran Pendidikan Jasmani

didapat sesuai dengan kondisi siswa dan sekolahnya. Akibat dari kekurangan media pendidikan jasmani, keterlibatan siswa dalam mengikuti aktivitas dalam kegiatan pendidikan jasmani diduga masih kurang baik ataupun rendah. Tidak sedikit siswa yang merasa gagal atau kaurang menyukai materi pembelajaran yang disampaikan oleh gurunya karena kemapuan guru dalam menyampaikan materi yang diberikan, baik dalam penggunaan fasilitas dan perlengkapn yang digunakan, dalam penyajian materi, dalam mengoptimalkan lingkungan pembelajaran maupun dalam mengevaluasi hasil pembelajaran.

\section{METODE}

\section{Jenis penelitian}

Jenis penelitian yang digunakan yaitu penelitian tindakan kelas (Classroom Action Research) yang dilakukan oleh guru untuk memperbaiki mutu praktek pembelajaran dikelas sebagai refleksi dari pembelajaran sebelumnya. Penelitian tindakan kelas (Classroom Action Research) berfokus pada kelas atau pada proses belajar mengajar yang terjadi dikelas, bukan pada input kelas (silabus, materi dan lain-lain) ataupun output (hasil belajar). Penelitian tindakan kelas (Classroom Action Research) harus tertuju atau mengenai hal-hal yang terjadi di dalam kelas.

Desain penelitian tindakan kelas (Classroom Action Research) yang digunakan berbentuk siklus yang tidak hanya berlangsung satu kali tetapi beberapa kali sehingga tercapai tujuan yang diharapkan. Desain penelitian tindakan kelas ini terdiri dari 3 siklus. Tiap siklus terdiri dari satu tindakan. Tiap siklus dilaksanakan sesuai dengan perubahan yang ingin dicapai.

Perubahan yang diinginkan akan tergambar pada pertanyaan penelitian. Untuk dapat melihat keterlibatan siswa dalam proses belajar mengajar pendidikan jasmani di kelas 4 maka akan dilakuakan pembelajaran sebagai observasi awal. Dan hasil evaluasi dan observasi awal maka dalam refleksi ditetapkan bahwa tindakan yang dipergunaklan untuk meningkatkan partisipasi siswa dalam pembelajaran penjas di kelas III adalah melalui permainan tradisional.

Dengan mengacu pada refleksi awal tersebut maka dilaksanakan penelitian tindakan kelas (Classroom Action Research) sesuai dengan model penelitian tindakan kelas menurut Stephen Kemmis dan Mc Taggart yang terdiri dari empat tahapan yang lazim dilalui, yaitu (1) perencanaan, (2) pelaksanaan, pengamatan, dan (4) refleksi.

\section{Populasi dan Sampel}

Populasi Penelitian tindakan kelas dilaksanakan pada siswa SDN Sarimulya I Desa Sarimulya Kecamatan Kotabaru Kabupaten Karawang dengan sampel penelitian adalah siswa kelas III sekolah dasar yang berjumlah 32 orang, yang diantaranya 18 orang anak laki-laki dan 
86 Neneng Suningsih ${ }^{1 *}$, Ega Trisna Rahayu ${ }^{2}$

Meningkatkan Waktu Aktif Belajar Siswa Sekolah Dasar

Melalui Pemanfaatan Media Pembelajaran Pendidikan Jasmani

14 orang anak perempuan. Di bawah ini daftar siswa kelas III SDN Sarimulya Desa Sarimulya Kecamatan Kota Baru Kabupaten Karawang.

Alasan penulis memilih kelas III karena kondisi kelas maupun siswanya itu sendiri sesuai dengan permasalahan yang diambil dengan pertimbangan masih banyaknya masalah yang terdapat di SDN Sarimulya dalam pembelajaran penjas, serta keterhubungan antara judul penelitian dengan masalah yang ada di SDN tersebut.

\section{Teknik Pengumpulan Data}

Teknik pengumpulan data dilakukan dengan mempergunakan pendekatan kualitatif melalui penelitian tindakan kelas (Classroom Action Research). Secara garis besar kegiatan pengumpulan data dilakukan melalui langkah-langkah sebagai berikut: (a) Menelaah seluruh data yang telah dikumpuikan, penelaahan dilakukan dengan cara menganalisis, memahami, menerangkan dan menyimpulkan. (b) Memproduksi data yang didalamnya tnelibatkan kegiatan pengkategorian dan pengklasifikasian hasil yang herlaku dalarn pelaksanaan pembelajaran. Dan (c) menyimpulkan dan mempverifikasi.

\section{Analisa Data}

Pada saat pembelajaran berlangsung peneliti melihat, memahami dan mengamati apa yang terjadi pada saat proses pembelajaran berlangsung. maka langkah-langkah peneliti untuk mengumpulkan data, dan teknik observasi yang digunakan sebagai berikut : (a) Observasi langsung, yaitu observasi yang dilakukan observer herada bersama objek yang diselidiki. Misalnya mengobservasi dan melihat skenario pembelajaran secara langsung. (b) Observasi tidak langsung, yaitu observer atau pengamatan yang dilakukan tidak pada saat berlangsungnya suatu peristiwa yang akan diteliti, misalnya berupa dokumentasi dan catatan lapangan. (c) Pengamatan dalam penilaian sikap atau variabel hasil belajar siswa yang berhubungan dengan peruhahan yang terjadi pada diri siswa yang berisi tentang: peningkatan keterampiIan, peningkatan kemampuan bermain. Peningkatan kebugaran jasmani, pengkatan tentang materi pelajaran dan sikap positif terhadap pendidikan jasamani olahraga.

Langkah selanjutnya adalah melakukan analisis dan refleksi terhadap semua data yang diperoleh dai hasil observasi dan penilaian, sehingga diketahui apakah penelitian yang telah dilakukan dapat meningkatkan hasil belajar siswa?. Selain data observasi dipergunakan pula skenario pembelajaran yang dibuat oleh peneliti sebagai acuan dapat mengevaluasi dirinya sendiri.

\section{HASIL dan PEMBAHASAN}

Sebelum melaksanakan tindakan, peneliti melaksanakan kegiatan pra observasi dengan tujuan untuk 
87 Neneng Suningsih ${ }^{1 *}$, Ega Trisna Rahayu ${ }^{2}$

Meningkatkan Waktu Aktif Belajar Siswa Sekolah Dasar

Melalui Pemanfaatan Media Pembelajaran Pendidikan Jasmani

mengidentifikasi masalah dalam

Hasil Rerata setiap Tindakan

penelitian tindakan kelas. Aktivitas

observasi awal ini dilaksanakan dan

dipusatkan pada pelaksanaan

pembelajaran yang bertujuan

untuk mengetahui sejauh mana

kegiatan belajar mengajar pendidikan jasmani yang dilaksanakan di SDN Sarimulya, sehingga dapat diangkat permasalahan yang terjadi dan mencari solusi dalam pemecahan masalah tesebut. Observasi paling utama dalam penelitian tindakan ini diarahkan pada masalah waktu aktif yang digunakan siswa dalam proses belajar. Hasil dari observasi awal ini adalah langkah sebagai gambaran untuk menentukan langkah-langkah tindakan kelas.

Pada pelaksaan beberapa tindakan dan dalam proses pembelajaran berlangsung, dalam upaya meningkatkan waktu aktif belajar melalui pemanfaatan media pembelajaran pendidikan jasmani, diketahi bahwa kemampuan siswa dalam setiap kegiatan mengalami sedikit perubahan yang dirasa cukup, meskipun demikian belum mencapai target yang telah ditentukan. Perubahan yang terjadi dan kategori aktifitas belajar (A), kategori instruksi (I), maupun kategori waiting (W), adapun hasil setiap tindakan dapat dilihat pada tabel di bawa ini.

Tabel 3.1.

\begin{tabular}{|l|c|c|c|l|l|}
\hline $\begin{array}{c}\text { Tind } \\
\text { a kan }\end{array}$ & $\mathbf{1}$ & $\mathbf{2}$ & $\mathbf{3}$ & $\begin{array}{c}\text { Juml } \\
\text { ah }\end{array}$ & $\begin{array}{l}\text { Rera } \\
\text { ta }\end{array}$ \\
\hline siklus & $\begin{array}{l}55,6 \\
\text { I }\end{array}$ & $\begin{array}{l}6 \%, 1 \\
6 \%\end{array}$ & $\begin{array}{l}65,5 \\
4 \%\end{array}$ & $\begin{array}{l}181,3 \\
4 \%\end{array}$ & $\begin{array}{l}60,45 \\
\%\end{array}$ \\
\hline siklus & $\begin{array}{l}74,1 \\
\text { II }\end{array}$ & $\begin{array}{l}7 \%, 9 \\
9 \%\end{array}$ & $\begin{array}{l}85,4 \\
2 \%\end{array}$ & $\begin{array}{l}238,5 \\
4 \%\end{array}$ & $\begin{array}{l}79,51 \\
\%\end{array}$ \\
\hline
\end{tabular}

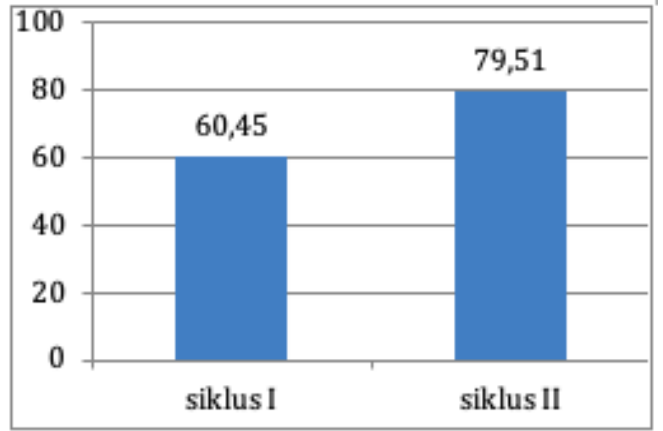

Berdasarkan diagram diatas bahwa penelitian ini memperlihatkan adanya peningkatan yang berarti pada tiap-tiap kategori dalam pembelajaran setelah siswa memperlihatkan respon yang cukup memuaskan ketika peneliti menerapkan metode pembelajaran dengan pemanfaatan media pembelajaran pendidikan jasmani yang ditandai dengan aktifitas siswa dalam PBM.

Hasil temuan dari tiap-tiap pelaksanaan tindakan penelitian ini adala sebagai berikut :

1. Pelaksanaan siklus 1 dengan rata-rata hasil tindakan pada seluruh kategori yaitu tindakan I 55,64\% tindakan II $60,16 \%$ dan tindakan III $65,54 \%$ meskipun ada perubahan porsentase aktivitas belajar, namun dirasa belum memuaskan dan belum mencapai target yang telah ditentukan. Terlihat siswa belum fokus pada media 
88 Neneng Suningsih ${ }^{1 *}$, Ega Trisna Rahayu ${ }^{2}$

Meningkatkan Waktu Aktif Belajar Siswa Sekolah Dasar

Melalui Pemanfaatan Media Pembelajaran Pendidikan Jasmani

pembelajaran yang dihadapi, sehingga tugas gerak tidak begitu baik dilakukan. Pada akhirnya siswa melakukan tugas gerak asal-asalan dan waktu aktif belajar kurang dimanfaatkan dengan baik.

2. Pada pelaksanaan siklus 2 dengan ratarata hasil tindakan pada keseluruhan kategori yaitu tindakan I 74,13\%, tindakan II 78,19\%, dan tindakan III $85,42 \%$, menunjukan adanya suatu perubahan yang sangat baik. perubahan ini terlihat mulai dari media pembelajaran yang digunakan banyak jumlahnya, kemudian pemberian instruksi yang jelas dan dapat di mengerti oleh siswa. Tindakan yang diberikan peneliti yaitu pemanfaatan media pembelajaran pendidikan jasmani dan memberi tugas gerak yang telah dijelaskan sebelum pembelajaran dimulai serta menyediakan alat belajar yang cukup sehingga tidak ada waktu yang terbuang pada saat proses pembelajaran.

Berdasarkan hasil analisis penelitian ini bahwa pada setiap kategori terjadi peningkatan yang merata meskipun pada siklus peningkatanya rendah dibandingkan dengan siklus 2. Hal ini disebabkan pada siklus 2 , media pembelajaranya sudah mulai menarik perhatian siswa, artinya seluruh siswa menggunakan alat belajar dan waktu menunggu untuk melakukan tugas gerak dapat diminimalisir.

\section{SIMPULAN}

Berdasarkan hasil analisis dan hasil pengolahan data, maka kesimpulan hasil penelitian pemanfaatan media pembelajaran pendidikan jasmani dalam upaya meningkatkan waktu aktif belajar siswa dalam latar belakang penelitian tindakan kelas memberikan peningkatan yang berarti dan signifikan terhadap waktu aktif belajar siswa, sehingga waktu aktif belajar menjadi lebi baik.

\section{DAFTAR PUSTAKA}

Agus, Mahendra (2006), Azas dan Falsafah pendidikan jasmani. Bandung : FPOK, UPI

Arikunto, Dkk. (2008), Penelitian Tindakan Kelas. Jakarta : PT Bumi Aksara.

Arsyad, Dkk. (2002). Media pembelajaran. Jakarta : PT Raja Grafindo Persada.

Muhamad Syamsul Taufik, Muhamad Guntur Gaos, 2019/11/1 Peningkatan Hasil Belajar Dribbling Sepakbola Dengan Penggunaan Media Audio Visual Jurnal, Jp. jok (Jurnal Pendidikan Jasmani, Olahraga dan Kesehatan) Jilid 3, 1 hlm. 43-54

Rahayu, Ega Trisna. (2016). Strategi Pembelajaran Pendidikan Jasmani. Bandung : Alfabeta. 
89 Neneng Suningsih ${ }^{1 *}$, Ega Trisna Rahayu ${ }^{2}$

Meningkatkan Waktu Aktif Belajar Siswa Sekolah Dasar

Melalui Pemanfaatan Media Pembelajaran Pendidikan Jasmani

Rusli, Lutan. (1997), Strategi Pembelajaran Pendidikan Jasmani dan Kesehatan, Depdikbud, Universitas Terbuka.

Sadiman, Dkk. (1993). Media Pendidikan. Jakarta : PT Raja Grafindo Persada.

Samsudin (2008), pembelajaran pendidikan jasmani olahraga dan kesehatan. Jakarta : PT Fajar Interpratama.

Samsudin. (2005). Pembelajaran Pendidikan Jasmani untuk Sekolah Dasar. Jakarta : PT Fajar Suharsimi, Arikunto (2006), Prosedur Penelitian Suatu Pendekantan Praktik. Jakarta : PT Rineka Cipta.

Suherman, Adang. (1998). Revitalisasi Keterlantaran Pengajaran Dalam Pendidikan Jasmani. Bandung : IKIP Bandung Press.

Yoyo, Bahagia (2003), Pengembangan Media Pengajaran Penjas. Jakarta : Direktorat Pendidikan Luar Biasa.

Yusuf, Hidayat (2007), Bahan Ajar

Penelitian Tindakan Kelas. Bandung :

FPOK, UPI

Interpratama 